\title{
Identification of Durum Wheat Cultivars and Their Tetraploid Relatives with Low Cadmium Content
}

\author{
Mehmet Tekin ${ }^{\top}$, Ahmet \\ Cat $^{2} \odot$, Sahriye Sönmez ${ }^{3} \odot$ \\ and Taner Akar ${ }^{1 *}$ (D) \\ 'Akdeniz University, Faculty of \\ Agriculture, Department of Field \\ Crops, 07059 Antalya, Turkey \\ ${ }^{2}$ Akdeniz University, Faculty of \\ Agriculture, Department of Plant \\ Protection, 07059 Antalya, Turkey \\ ${ }^{3}$ Akdeniz University, Faculty of \\ Agriculture, Department of Soil \\ Science, 07059 Antalya, Turkey
}

Received: 8 October 2019 Accepted: 29 March 2020

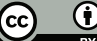

\section{SUMMARY}

In this study, 71 durum wheat cultivars (Triticum durum Desf.), 22 emmer wheat (Triticum dicoccum L.) and 11 wild emmer (Triticum dicoccoides L.) genotypes were genetically characterized to determine the alleles associated with high cadmium (Cd) content. After genotypic characterization, 14 cultivars selected among all genotypes with low and high Cd content were phenotyped by a pot experiment to verify the genotypic data. Identification of $32 \mathrm{du}$ rum wheat, one emmer wheat and four wild emmer genotypes showed that they have alleles associated with high $\mathrm{Cd}$ content, while 68 genotypes of which 39 durum wheat, 21 emmer wheat and 7 wild emmer cultivars had alleles associated with low Cd content. Moreover, phenotypic data obtained from pot experiment were similar to the molecular data. To sum up, the marker successfully classified durum wheat cultivars into either high or low accumulators and these results can be safely used in breeding programs to improve new durum wheat cultivars with alleles associated with low $\mathrm{Cd}$ content. Due to routine use of phosphorus fertilizers in agricultural areas and other anthropogenic factors related to $\mathrm{Cd}$ toxicity, new durum wheat cultivars with low $\mathrm{Cd}$ content should be urgently developed for safe production of macaroni or other types of wheat products for human and animal consumption.

Key words: durum wheat characterization, low Cd content, tetraploid wheat, marker assisted breeding

\section{INTRODUCTION}

The accumulation of heavy metals in the soil has a major impact on the environment. Heavy metals accumulated in the soil are stored in plant tissues over time and, therefore, pose a threat to human and animal health $(1,2)$. Cadmium $(\mathrm{Cd})$ is one of the toxic metals which cause very serious health problems for humans. So far, diseases caused by $\mathrm{Cd}$ such as itai-itai have been diagnosed (2). Metal industry, fossil fuels, domestic waste, application of pesticide and phosphorus fertilizers are the greatest sources of $\mathrm{Cd}$ pollution (3). Moreover, $30000 \mathrm{t}$ of $\mathrm{Cd}$ are added to environment annually and $13000 \mathrm{t}$ of these are caused by human activities (4). Many countries have determined several restrictions for the mass fraction of $\mathrm{Cd}$ in phosphorus fertilizers. Germany for instance has limited the $\mathrm{Cd}$ mass fraction in phosphorus fertilizers to $200 \mathrm{mg} / \mathrm{kg}$ (5). In Sweden, phosphorus fertilizers have been subjected to taxes when the Cd mass fraction exceeds $5 \mathrm{mg} / \mathrm{kg}$ and imports of phosphorous fertilizers with a Cd mass fraction above $100 \mathrm{mg} / \mathrm{kg}$ are prohibited (6). This implementation encourages the production of low-Cd fertilizers and reduces $\mathrm{Cd}$ input into the soil.

$\mathrm{Cd}$ is mostly accumulated in the human body through food consumption, mainly thanks to a high intake of cereals. It is known that the contribution of cereal products to daily Cd intake ranges from 20 to $43 \%$ (7). Wheat (Triticum L.) is the first among the cultivated plants in terms of production and harvested area worldwide and wheat products provide $20 \%$ of the daily calories and also $20 \%$ of the protein, especially in 94 developing countries with more than 4.5 billion people (8). There is a large genetic variation especially in durum wheat (Triticum durum Desf.) regarding $\mathrm{Cd}$ accumulation in the grain and it is known that this species has higher Cd content than other cool season cereals: rye $<$ barley $<$ oat $<$ bread wheat $<$ durum wheat (6-9). Food and Agriculture Organization of the United Nations (FAO) and The International Codex 
Alimentarius Commission of World Health Organization (WHO) have standardized the maximum allowable $\mathrm{Cd}$ mass fraction in wheat grain to be $0.1 \mathrm{mg} / \mathrm{kg}$ (10). In order to reduce Cd uptake and toxicity, many alternative methods such as the use of plant growth regulators and plant nutrients are applied (2). However, the most environmentally friendly and efficient strategy are the development of new genetic materials with low cadmium content (2) and breeding programs have been carried out in many countries for this purpose. For instance, in Canada, where $\mathrm{Cd}$ is one of the most serious environmental problems, durum wheat cultivars have been developed since 2003 via marker-assisted selection (MAS) (11-13). A major gene Cdu1 (14), which is located in the long arm of chromosome $5 \mathrm{~B}$, controls the $\mathrm{Cd}$ accumulation in durum wheat $(15,16)$. Several tightly linked markers with gene $C d u 1$ have been developed to detect the allele associated with low content of $C d$ in durum wheat such as dominant SCAR marker SCOPC20 (15) and co-dominant CAPS marker usw47 (17). These markers can be used to characterize $\mathrm{Cd}$ accumulation in both tetraploid durum wheat and other tetraploid wheat relatives such as emmer (Triticum dicoccum L.) and wild emmer (Triticum dicoccoides L.).

The aim of the study is to molecularly characterize Turkish durum wheat gene pool and some emmer wheat and wild emmer genotypes via usw47 marker for allele associated with low $\mathrm{Cd}$ content. Additionally, some selected durum wheat cultivars with alleles associated with low or high Cd content were tested in pot experiment to verify the molecular data.

\section{MATERIALS AND METHODS}

\section{Genetic materials}

Seventy-one durum wheat (Triticum durum Desf.) cultivars and advanced breeding lines with 2 universal controls, 24 emmer wheat (Triticum dicoccum L.) genotypes and 11 wild emmer (Triticum dicoccoides L.) genotypes (Table 1) were used as genetic materials in this study. Canadian durum wheat cultivar

Table 1. Different tetraploid germplasm materials used in the study

\begin{tabular}{|c|c|c|c|c|c|c|c|c|}
\hline No. & Species & Genotype & No. & Species & Genotype & No. & Species & Genotype \\
\hline 1 & Triticum durum Desf. & Zenit & 37 & Triticum durum Desf. & Tunca 79 & 73 & Triticum durum Desf. & Dt 812 \\
\hline 2 & Triticum durum Desf. & Svevo & 38 & Triticum durum Desf. & Ankara 98 & 74 & Triticum dicoccum L. & TR79489 \\
\hline 3 & Triticum durum Desf. & Saragolla & 39 & Triticum durum Desf. & Sis gd $14 \mathrm{v}$ & 75 & Triticum dicoccum L. & TR61225 \\
\hline 4 & Triticum durum Desf. & Claudio & 40 & Triticum durum Desf. & Sis gd $14 \mathrm{e}$ & 76 & Triticum dicoccum L. & TR69596 \\
\hline 5 & Triticum durum Desf. & Aydın 93 & 41 & Triticum durum Desf. & Sis gd $14 \mathrm{c}$ & 77 & Triticum dicoccum L. & TR69623 \\
\hline 6 & Triticum durum Desf. & Ege 88 & 42 & Triticum durum Desf. & 5 & 78 & Triticum dicoccum L. & TR68784 \\
\hline 7 & Triticum durum Desf. & Firat 93 & 43 & Triticum durum Desf. & 6 & 79 & Triticum dicoccum L. & TR68789 \\
\hline 8 & Triticum durum Desf. & Fuatbey 2000 & 44 & Triticum durum Desf. & 12 & 80 & Triticum dicoccum L. & TR68817 \\
\hline 9 & Triticum durum Desf. & Gap & 45 & Triticum durum Desf. & 14 & 81 & Triticum dicoccum L. & TR68857 \\
\hline 10 & Triticum durum Desf. & Gediz 75 & 46 & Triticum durum Desf. & 22 & 82 & Triticum dicoccum L. & TR69632 \\
\hline 11 & Triticum durum Desf. & Harran 95 & 47 & Triticum durum Desf. & 29 & 83 & Triticum dicoccum L. & TR72183 \\
\hline 12 & Triticum durum Desf. & Sarıçanak 98 & 48 & Triticum durum Desf. & 47 & 84 & Triticum dicoccum L. & Advanced line 5 \\
\hline 13 & Triticum durum Desf. & Şölen 2002 & 49 & Triticum durum Desf. & 50 & 85 & Triticum dicoccum L. & Advanced line 6 \\
\hline 14 & Triticum durum Desf. & Turabi & 50 & Triticum durum Desf. & 57 & 86 & Triticum dicoccum L. & Advanced line 11 \\
\hline 15 & Triticum durum Desf. & Tüten 2002 & 51 & Triticum durum Desf. & 69 & 87 & Triticum dicoccum L. & Advanced line 13 \\
\hline 16 & Triticum durum Desf. & Diyarbakır 81 & 52 & Triticum durum Desf. & 71 & 88 & Triticum dicoccum L. & Advanced line 14 \\
\hline 17 & Triticum durum Desf. & Altıntaş 95 & 53 & Triticum durum Desf. & 72 & 89 & Triticum dicoccum L. & Advanc \\
\hline 18 & Triticum durum Desf. & Amanos 97 & 54 & Triticum durum Desf. & 75 & 90 & Triticum dicoccum L. & Advanced line 24 \\
\hline 19 & Triticum durum Desf. & Maestrale & 55 & Triticum durum Desf. & 101 & 91 & Triticum dicoccum L. & Advanced line 35 \\
\hline 20 & Triticum durum Desf. & Aurea & 56 & Triticum durum Desf. & 102 & 92 & Triticum dicoccum L. & Advanced line 42 \\
\hline 21 & Triticum durum Desf. & Normanno & 57 & Triticum durum Desf. & 103 & 93 & Triticum dicoccum L. & Advanced line 50 \\
\hline 22 & Triticum durum Desf. & Gracale & 58 & Triticum durum Desf. & 106 & 94 & Triticum dicoccum L. & Advanced line 52 \\
\hline 23 & Triticum durum Desf. & Levante & 59 & Triticum durum Desf. & 107 & 95 & Triticum dicoccum L. & Advanced line 53 \\
\hline 24 & Triticum durum Desf. & Kunduru 1149 & 60 & Triticum durum Desf. & 110 & 96 & Triticum dicoccum L. & Advanced line 57 \\
\hline 25 & Triticum durum Desf. & Eminbey & 61 & Triticum durum Desf. & 111 & 97 & Triticum dicoccum L. & Advanced line 60 \\
\hline 26 & Triticum durum Desf. & Kamut & 62 & Triticum durum Desf. & Dww tk 4 & 98 & Triticum dicoccoides $\mathrm{L}$ & TGB 00777 \\
\hline 27 & Triticum durum Desf. & Çeşit 1252 & 63 & Triticum durum Desf. & Dww tk 11 & 99 & Triticum dicoccoides $\mathrm{L}$ & TGB 00791 \\
\hline 28 & Triticum durum Desf. & Dumlupınar & 64 & Triticum durum Desf. & Dww tk 12 & 100 & Triticum dicoccoides $\mathrm{L}$ & TGB 000792 \\
\hline 29 & Triticum durum Desf. & Kızıltan 91 & 65 & Triticum durum Desf. & Dww tk 14 & 101 & Triticum dicoccoides $\mathrm{L}$ & TGB 045861 \\
\hline 30 & Triticum durum Desf. & Meram 2002 & 66 & Triticum durum Desf. & Dww tk 15 & 102 & Triticum dicoccoides $\mathrm{L}$ & TGB 045871 \\
\hline 31 & Triticum durum Desf. & Mirzabey 2000 & 67 & Triticum durum Desf. & Kocasarı 2-3 & 103 & Triticum dicoccoides $\mathrm{L}$. & TGB 045910 \\
\hline 31 & Triticum durum Desf. & Yelken & 68 & Triticum durum Desf. & Kocasarı 4-1 & 104 & Triticum dicoccoides $\mathrm{L}$ & TGB 045911 \\
\hline 33 & Triticum durum Desf. & Selçuklu 97 & 69 & Triticum durum Desf. & Kocasarı 8-2 & 105 & Triticum dicoccoides $\mathrm{L}$ & TGB 045912 \\
\hline 34 & Triticum durum Desf. & Altın 40/98 & 70 & Triticum durum Desf. & Kocasarı 9-1 & 106 & Triticum dicoccoides $\mathrm{L}$ & TGB 045913 \\
\hline 35 & Triticum durum Desf. & Kunduru414/44 & 71 & Triticum durum Desf. & Kocasarı 16-1 & 107 & Triticum dicoccoides $\mathrm{L}$ & TGB 045920 \\
\hline 36 & Triticum durum Desf. & Yılmaz 98 & 72 & Triticum durum Desf. & Commander & 108 & Triticum dicoccoides $\mathrm{L}$ & TGB 038501 \\
\hline
\end{tabular}

74-83 emmer and 98-108 wild emmer genotypes were obtained from Turkish Seed Gene Bank (Ankara, Turkey), 84-97 emmer genotypes were developed in a project funded by TUBITAK (The Scientific and Technological Research Council of Turkey, project no. 2140401) 
Commander and advanced line Dt 812 kindly provided by Dr Y. Ruan from Agriculture and Agri-Food Canada were used as negative and positive control, respectively. Ten emmer wheat and all wild emmer genotypes were obtained from Turkish Seed Gene Bank (Ankara, Turkey). Other emmer wheat lines used in the study were developed via selective breeding in a project funded by TUBITAK (The Scientific and Technological Research Council of Turkey, Project no. 2140401).

\section{Genetic characterization}

Seeds of all genotypes were sown on trays and then leaf samples were collected from plants for DNA extraction at 2-3 leaf stage. DNA was extracted according to cetyl trimethylammonium bromide (CTAB) method (18). The extracted DNA samples were loaded on agarose gel (Biomax, Thomas Scientific, Swedesboro, NJ, USA) with a DNA standard in order to determine the quality and concentration of the DNA and then were stored in sterile distilled water at $-20^{\circ} \mathrm{C}$ until use. To amplify Cdu1 gene alleles by PCR, the co-dominant CAPS marker usw47, which was derived from an expressed sequence tag (EST) XBF474090 co-segregating with Cdu1 (16), was used.

PCR was carried out as follows: the total volume of the reaction mixture was $15 \mu \mathrm{L}$ containing $100 \mathrm{ng}$ genomic DNA, $1 \times$ PCR buffer (Sigma Aldrich, Merck, St. Louis, MO, USA), $1.5 \mathrm{mM}$ $\mathrm{MgCl}_{2}$ (Sigma Aldrich, Merck), $0.2 \mathrm{mM}$ of dNTP mix (Thermo Fisher Scientific, Waltham, MA, USA) $0.4 \mu \mathrm{M}$ of usw47 forward primer (5'-GCTAGGACTTGATTCATTGAT-3'), $0.4 \mu \mathrm{M}$ of usw47 reverse primer (5'-AGTGATCTAAACGTTCTTATA-3'), 1.25 U Taq DNA polymerase (Sigma Aldrich, Merck). Amplification was performed in a thermocycler (MyGenie ${ }^{\mathrm{TM}}$ 96; Bioneer, Daejon, Korea) under the following conditions: $94^{\circ} \mathrm{C}$ initial denaturation for $5 \mathrm{~min}, 30$ cycles at $94^{\circ} \mathrm{C}$ for $30 \mathrm{~s}$, annealing temperature $55^{\circ} \mathrm{C}$ for $30 \mathrm{~s}, 72{ }^{\circ} \mathrm{C}$ for $1 \mathrm{~min}$, and then a final extension of $10 \mathrm{~min}$ at $72^{\circ} \mathrm{C}$.

The PCR products were digested by Hpy188I (New England Biolabs, Ipswich, MA, USA) restriction enzyme after amplification. The total volume of the reaction mixture for enzymatic digestion was $15 \mu \mathrm{L}$ containing $4 \mu \mathrm{L}$ PCR product, $0.25 \mu \mathrm{L}$ Hpy 188 I gene from Helicobacter pylori, 1× NEBuffer 4 (New England Biolabs) and 9.25 $\mu \mathrm{L}$ distilled water. Enzymatic digestion was performed in a thermo-shaker (Biosan, Riga, Latvia) under the following conditions: $37^{\circ} \mathrm{C}$ for $1 \mathrm{~h}, 65^{\circ} \mathrm{C}$ for $20 \mathrm{~min}$ and holding at $10^{\circ} \mathrm{C}$ for $5 \mathrm{~min}$ and then the products were loaded in $2 \%$ agarose gel and visualized under UV light after staining with ethidium bromide (Sigma Aldrich, Merck).

\section{Pot experiment and elemental analysis}

After molecular analysis, a small set of commonly cultivated 14 genotypes (Ege-88, Amanos-97, Sarıçanak 98, Şölen 2002, Turabi, Svevo, Zenit, Firat-93, Fuatbey 2000, GAP, Gediz 75, Tüten 2002, Diyarbakır and Levante) was grown in pots in three replicates. The soil was mixed with acidic peat, in 1:1 ratio to increase the $\mathrm{Cd}$ uptake by plants, and then each pot was filled in with $2 \mathrm{~kg}$ of the mixture. A volume of $10 \mathrm{~mL}$ of
$\mathrm{CdCl}_{2} \cdot \mathrm{H}_{2} \mathrm{O}$ (Merck, Darmstadt, Germany) was added to each pot with automatic pipette to achieve final $\mathrm{Cd}$ mass fraction of $8 \mathrm{mg} / \mathrm{kg}$. At physiologically ripening stage based on Zadoks growth scale (Z 98), grain and stem parts were sampled for each genotype and the samples were dried at $70^{\circ} \mathrm{C}$ to constant mass. Dried plant samples of $0.5 \mathrm{~g}$ each were digested with $10 \mathrm{~mL} \mathrm{HNO}_{3} / \mathrm{HClO}_{4}$ acid (4:1; Merck) mixture on a hotplate. The samples were then heated until a clear solution was obtained. The same procedure was repeated several times. The samples were filtered and diluted to $100 \mathrm{~mL}$ using distilled water, and then $\mathrm{Cd}$ mass fraction of the combusted samples with other elements such as $\mathrm{P}, \mathrm{Mg}, \mathrm{Ca}, \mathrm{K}, \mathrm{Zn}, \mathrm{Cu}, \mathrm{Fe}$ and $\mathrm{Mn}$ was measured by inductively coupled plasma-optical emission spectrometer (ICP-OES) (Optima, PerkinElmer Inc., Waltham, MA, USA). Additionally, soil in each pot was analyzed to determine total $\mathrm{Cd}$ accumulation from the soil in the biomass of each genotype at the end of the pot experiment.

\section{Statistical analysis}

Basic statistical parameters such as mean and standard error of mean were determined. Analysis of variance (ANOVA) was performed with least significant difference (LSD) test at the $95 \%$ confidence level using SAS statistical software (19). Additionally, correlation and principal component analyses (PCA) were performed to determine relationships among the elements by XLSTAT statistical software (20).

\section{RESULTS AND DISCUSSION}

\section{Genetic characterization}

Fig. 1 shows the results of PCR analysis of alleles associated with the accumulation of $\mathrm{Cd}$ obtained from usw47 marker. According to banding patterns of usw47, there are three possible alleles: for low $\mathrm{Cd}$ content, high $\mathrm{Cd}$ content and heterogeneous. Fig. S1 and Fig. S2 show all gel visualizations obtained from molecular analysis. Genotyping results of 108 tested tetraploid wheats are shown in Table 2.

Based on the molecular analysis, 21 (52.5\%) out of 40 durum wheat cultivars had alleles associated with high and 12 (47.5\%) with low Cd content, and 19 (36.4\%) out of 33

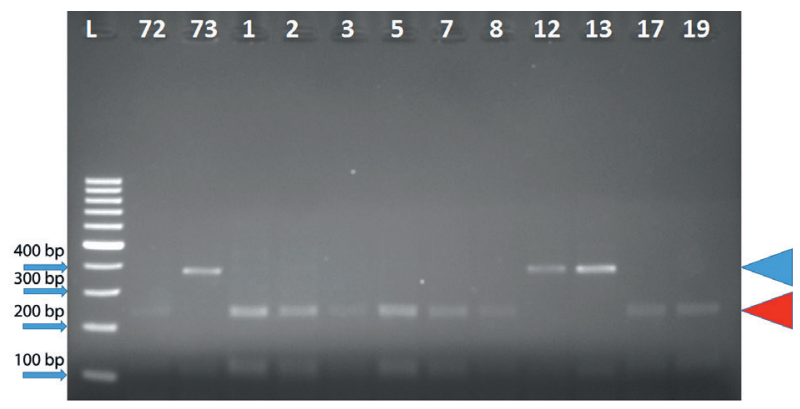

Fig. 1. Results of PCR analysis of durum wheat alleles associated with the accumulation of Cd obtained from usw47 marker. Red and blue symbols illustrate alleles associated with high and low content of Cd, respectively 
advanced breeding lines had alleles associated with high and 21 (63.6 \%) with low Cd content (Table 2 and Fig. S1). Additionally, only 1 (4\%) of the 24 emmer wheat genotypes had alleles associated with high Cd content, and 7 (63.6\%) of 11 wild emmer genotypes with low and 4 (36.4\%) with high Cd content (Table 2 and Fig. S2). Similar results were obtained by Zimmerl et al. (17), who reported 166 (53\%) of 314 tetraploid wheat genotypes associated with low Cd content and usw47 marker can be successfully used to determine low Cd accumulators in tetraploid wheat accessions. Moreover, Vergine et al. (21) also genetically characterized tetraploid genotypes by a sequence-characterized amplified region (SCAR) marker, ScOPC20 in terms of $\mathrm{Cd}$ accumulation. However, this marker allows to display two different alleles: one associated with low Cd content (band absent) and another with high Cd content (band present), therefore, heterogeneous state cannot be detected.

\section{Elemental analysis based on pot experiment}

Fig. 2 shows $\mathrm{Cd}$ mass fractions in the grain, stem and underground parts of fourteen durum wheat cultivars. The results in Fig. 2a demonstrate that Cd addition $(8 \mathrm{mg} / \mathrm{kg}$ ) to the soil mixture clearly increases $\mathrm{Cd}$ accumulation in the grain. The cultivar Diyarbakır was the highest accumulator of $\mathrm{Cd}$ in the grain in both control and samples with added $\mathrm{Cd}(0.38$ and $0.91 \mathrm{mg} / \mathrm{kg}$ respectively, Fig. 2a), while the control sample of Turabi cultivar and the sample of Amanos-97 cultivar grown in the soil with added $\mathrm{Cd}$ had the lowest $\mathrm{Cd}$ content in grain (0.1 and $0.12 \mathrm{mg} / \mathrm{kg}$ respectively, Table S1). All cultivars used in pot experiment except Amanos-97 and Sarıçanak 98 accumulated more $\mathrm{Cd}$ in grains after the addition of $\mathrm{Cd}$ to the soil (Table S1). In addition to cadmium, phosphorus, potassium, calcium, magnesium, iron, zinc, copper and manganese mass fractions were also determined (Table S1). A two-way ANOVA showed a significant difference $(p<0.01)$ in the

Table 2. Determination of alleles of durum wheat cultivars associated with low and high Cd content based on molecular analysis

\begin{tabular}{|c|c|c|c|c|c|}
\hline No. & Molecular evaluation & No. & Molecular evaluation & No. & Molecular evaluation \\
\hline 1 & High & 37 & High & 73 & Low \\
\hline 2 & High & 38 & Low & 74 & Low \\
\hline 3 & High & 39 & Low & 75 & Low \\
\hline 4 & Low & 40 & Low & 76 & Low \\
\hline 5 & High & 41 & High & 77 & Low \\
\hline 6 & Low & 42 & Low & 78 & High \\
\hline 7 & High & 43 & High & 79 & Low \\
\hline 8 & High & 44 & Low & 80 & Low \\
\hline 9 & High & 45 & High & 81 & Low \\
\hline 10 & High & 46 & Low & 82 & Low \\
\hline 11 & High & 47 & Low & 83 & Low \\
\hline 12 & Low & 48 & Low & 84 & Low \\
\hline 13 & Low & 49 & Low & 85 & Low \\
\hline 14 & Low & 50 & Low & 86 & Low \\
\hline 15 & High & 51 & Low & 87 & Low \\
\hline 16 & High & 52 & High & 88 & Low \\
\hline 17 & High & 53 & High & 89 & Low \\
\hline 18 & Low & 54 & High & 90 & Low \\
\hline 19 & High & 55 & Low & 91 & Low \\
\hline 20 & High & 56 & Low & 92 & Low \\
\hline 21 & High & 57 & Low & 93 & Low \\
\hline 22 & Low & 58 & High & 94 & Low \\
\hline 23 & High & 59 & Low & 95 & Low \\
\hline 24 & Low & 60 & High & 96 & Low \\
\hline 25 & Low & 61 & Low & 97 & Low \\
\hline 26 & High & 62 & Low & 98 & Low \\
\hline 27 & Low & 63 & High & 99 & Low \\
\hline 28 & Low & 64 & High & 100 & High \\
\hline 29 & Low & 65 & High & 101 & Low \\
\hline 30 & Low & 66 & High & 102 & High \\
\hline 31 & Low & 67 & Low & 103 & High \\
\hline 31 & Low & 68 & Low & 104 & Low \\
\hline 33 & High & 69 & Low & 105 & Low \\
\hline 34 & Low & 70 & Low & 106 & Low \\
\hline 35 & Low & 71 & Low & 107 & Low \\
\hline 36 & High & 72 & High & 108 & High \\
\hline
\end{tabular}


a)

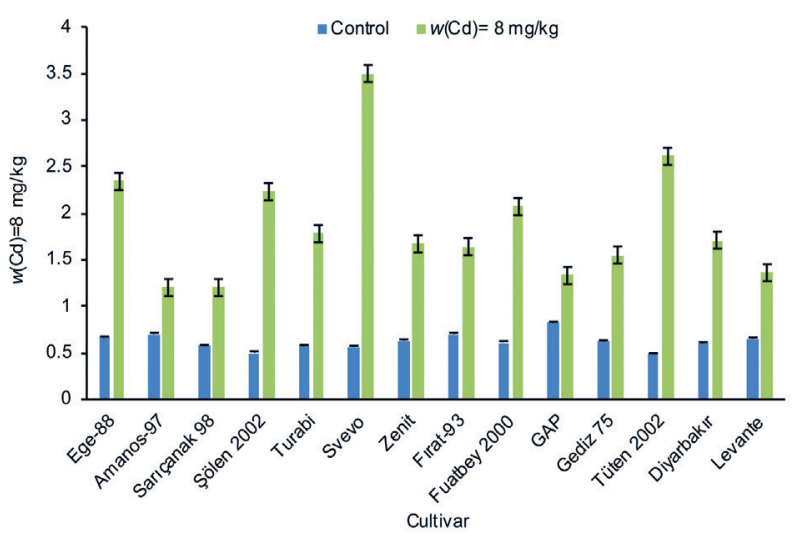

b)

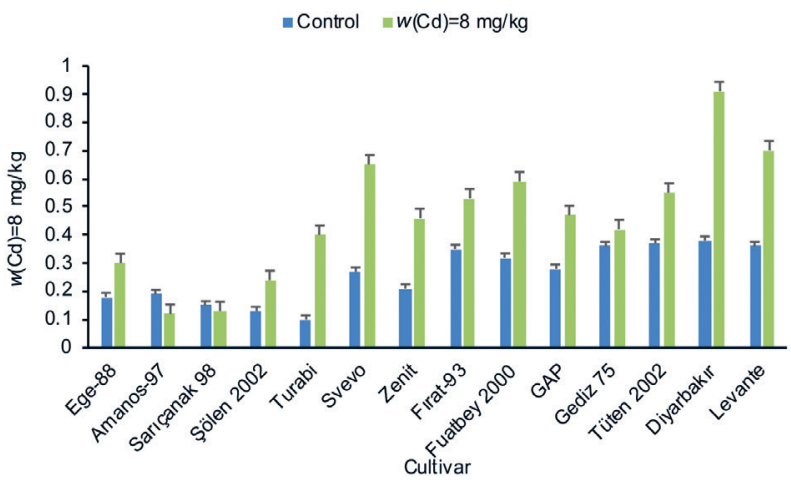

c)

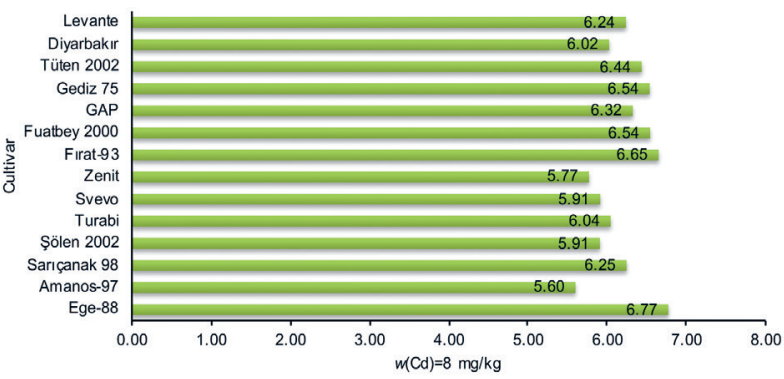

Fig. 2. Mass fractions of $(d$ in: a) grain, b) stem and c) underground parts of durum wheat cultivars in both control and samples grown in the soil with the addition of $w(\mathrm{Cd})=8 \mathrm{mg} / \mathrm{kg}$

mass fractions of these elements among cultivars. Moreover, taking into account cultivar $\times$ treatment interaction, a significant difference was found in the mass fractions of all elements at the $p=0.01$ except for phosphorus $(p<0.05)$. As expected, phenotypic data obtained from pot experiment for $\mathrm{Cd}$ accumulation in the grain were similar to molecular data. Low mass fraction of Cd was found in cultivars Ege-88, Amanos-97, Sarıçanak 98, Sölen 2002 and Turabi, which have the allele associated with low Cd content (Fig. 2a). Zimmerl et al. (17) and Perrier et al. (22) reported that varieties with the allele associated with high $\mathrm{Cd}$ content had 2.4-fold more $\mathrm{Cd}$ in the grain than the varieties with the allele associated with low Cd content.
In addition to grain, stem $\mathrm{Cd}$ mass fractions were determined (Fig. 2b). The addition of Cd ( $8 \mathrm{mg} / \mathrm{kg}$ ) to the soil mixture increased the stem $\mathrm{Cd}$ mass fraction in almost all cultivars used in pot experiment. Moreover, among control samples, Gap cultivar had the highest stem $\mathrm{Cd}$ mass fraction, while Tüten 2002 cultivar had the lowest (Fig. 2b and Table S2). Durum wheat cultivars with low $\mathrm{Cd}$ mass fraction in their stems can be beneficial feed sources especially for small ruminants that graze on wheat stems and leaves after grain harvest under rainfed conditions in Turkey. Svevo cultivar also had the highest stem $\mathrm{Cd}$ mass fraction in addition to its high grain $\mathrm{Cd}$ accumulation (Fig. $2 \mathrm{~b}$ ). The results of a two-way ANOVA show that there were significant differences $(p<0.01)$ in mass fractions of all elements determined in stem for cultivar and cultivar $\times$ treatment interaction (Table S2). On the other hand, $\mathrm{Cd}$ mass fractions in underground parts (roots and stubble) of cultivars grown in the soil with the addition of $8 \mathrm{mg} / \mathrm{kg} \mathrm{Cd}$ were also determined and the results showed that most of the added Cd was accumulated by the plants (Fig. 2c). While Amanos-97 cultivar had the lowest $\mathrm{Cd}$ mass fraction in each organ in general, Ege-88 cultivar had the highest $\mathrm{Cd}$ mass fraction in the underground parts in particular (Fig 2c). Considering Cd distribution in plant organs, most of the Cd was found in the underground parts, in which cultivars with the alleles associated with low $\mathrm{Cd}$ content had $4.13 \mathrm{mg} / \mathrm{kg}$, i.e. $67 \%$ total Cd (Fig. 3a), whereas those containing alleles associated with high Cd content had $3.75 \mathrm{mg} / \mathrm{kg}$, i.e. $60 \%$ of the total $\mathrm{Cd}$ (Fig. 3b).

a)

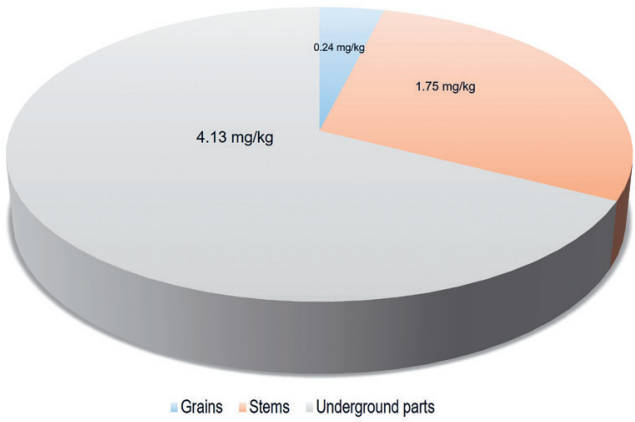

b)

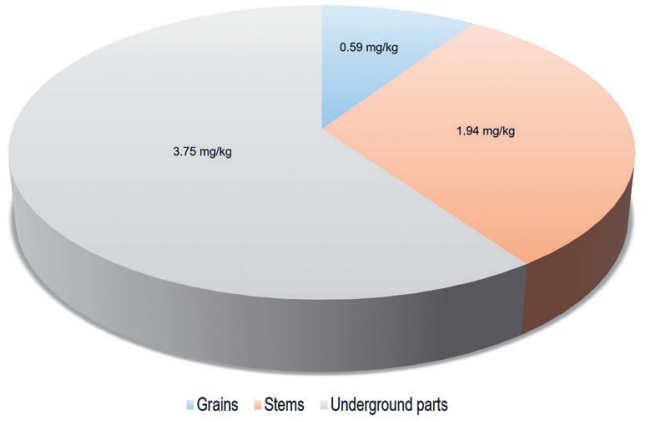

Fig. 3. Distribution of Cd content in durum wheat organs of: a) cultivars with alleles associated with low and b) high $\mathrm{Cd}$ content 


\section{Correlation and multivariate analyses} of $C d$ mass fraction in the grain

In order to understand the relationships among elements, correlation analysis was performed (Table 3). There was a negative correlation between the grain $\mathrm{Cd}$ and $\mathrm{Cu}(r=-0.76, \mathrm{p}<0.01)$ and $\mathrm{Mn}(r=-0.56, \mathrm{p}<0.01)$ in the control samples. Grain Cd was also negatively correlated with $\mathrm{Mg}(r=-0.55, \mathrm{p}<0.01)$ in the grain samples grown in soil with added $\mathrm{Cd}$ (Table 3). An opposite finding was reported by Perrier et al. (22) that grain Cd was positively correlated with $\mathrm{Mn}(r=0.61, \mathrm{p}<0.01)$ and $\mathrm{Mg}(r=0.38$, $\mathrm{p}<0.05$ ). In addition to these, there was a non-significant correlation between the grain $\mathrm{Cd}$ and $\mathrm{Cu}$ (22). Liu et al. (23) also studied correlations between $\mathrm{Cd}$ and mineral nutrients in parts of roots and leaves in rice and they reported that $\mathrm{Cd}^{2+}$ was generally correlated with $\mathrm{Fe}^{3+}, \mathrm{Mn}^{2+}, \mathrm{Cu}^{2+}$ and $\mathrm{Mg}^{2+}$. Jalil et al. (24) conducted a similar study of durum wheat with different $\mathrm{Cd}$ mass fractions added to nutrient solution and they reported that for all of them, the mass fractions of Mn, Zn, Cu and Fe were not affected significantly but $\mathrm{Cd}$ additions to the solution depressed the uptake of $\mathrm{Zn}$ and $\mathrm{Mn}$. A similar negative interaction between $\mathrm{Cd}$ and $\mathrm{Mn}$ was also found in this study.

Additionally, principal component analysis (PCA) was performed to determine the relationships between genotypes and plant organs (Fig. 4). PCA showed that the first two components (PC1 and PC2) accounted for $96.31 \%$ of the total variance. PC1 explained $70.18 \%$ variance, while PC2 elucidated $26.13 \%$ of the total variance (Fig. 4). Moreover, contribution of each plant organ to the $\mathrm{PC} 1$ and $\mathrm{PC} 2$ shows that $\mathrm{Cd}$ in the underground parts of plant (43.51) was major contributor to PC1, whereas Cd in the grain (79.72) mainly contributed to PC2 (Table 4). Vergine et al. (21) similarly performed PCA for determination of Cd mass fraction in durum wheat and they reported that roots and kernels contributed to PC1 and grains mostly contributed to PC2. As a result of biplot visualization, different groups were revealed for each plant organ such as underground part (shoots and roots), stem and grain (Fig. 4). Each circle represents different group of $\mathrm{Cd}$ mass fractions in each plant organ in the bi-plot graph. The Diyarbakır and Levante cultivars, marked with yellow colour, accumulate the highest mass fractions of $\mathrm{Cd}$ in the grain. The second group marked with green consists of Svevo and Tüten 2002 cultivars, which had the highest mass fractions of $\mathrm{Cd}$ in the stem. The third group marked with blue colour comprises Amanos-97 and Sarıçanak 98 cultivars, which accumulate high mass fractions of $C d$ in the root. All other cultivars, Firat-93, GAP, Fuatbey-2000, Zenit, Gediz 75, Turabi and Ege-88, had lower Cd mass fractions in all plant organs (Fig. 4). Svevo cultivars accumulated the highest mass fraction of Cd in both grain and stem, while Amanos-97 cultivar had the lowest mass fraction of $C d$ in the stem and grain. At this point, difference in the root to grain translocation of $\mathrm{Cd}$ among durum wheat genotypes is very important to develop new cultivars that can be grown in Cd-contaminated soils. If this translocation is weak or root sequestrates the Cd efficiently, grain Cd content will be low $(25,26)$. In addition to this, partitioning of $\mathrm{Cd}$ among plant organs is the second important strategy for low Cd mass fraction in the grain. Perrier et al. (22) highlighted that growing long-stemmed cultivars may have advantages since lower mass fractions of $\mathrm{Cd}$ are moved to plant organs such as stem, leaves, bracts, rachis and

Table 3. Correlations between $\mathrm{Cd}$ and other elements in the grain of control samples and samples grown in soil with the addition of $w(\mathrm{Cd})=8 \mathrm{mg} / \mathrm{kg}$

$\begin{array}{lcccccccc}\text { Treatment } & \mathrm{P} & \mathrm{K} & \mathrm{Ca} & \mathrm{Mg} & \mathrm{Fe} & \mathrm{Zn} & \mathrm{Cu} & \mathrm{Mn} \\ \text { Control } & -0.32 & -0.08 & -0.28 & 0.15 & -0.26 & -0.21 & -0.76^{*} & -0.56^{*} \\ w(\mathrm{Cd})=8 \mathrm{mg} / \mathrm{kg} & -0.27 & 0.36 & 0.27 & -0.55^{*} & -0.35 & -0.19 & -0.48 & -0.31 \\ { }^{*} \mathrm{p}<0.01 & & & & & & & & \end{array}$

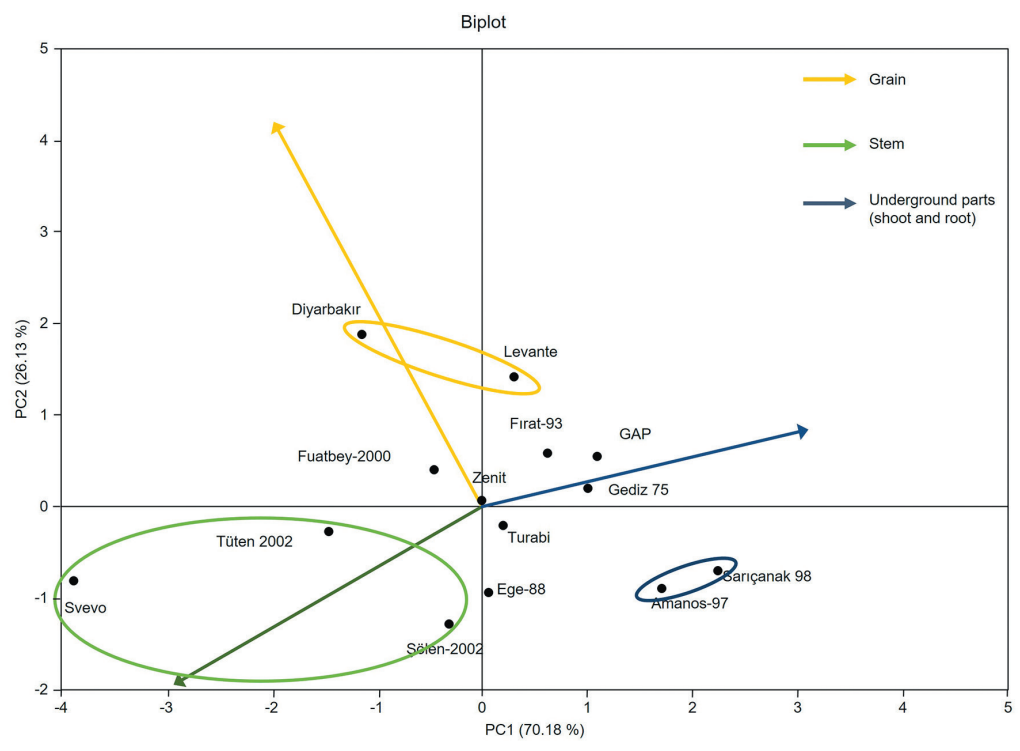

Fig. 4. Bi-plot obtained with principal component analysis (PCA) of Cd mass fractions in plant organs of different durum wheat cultivars 
grains. Arduini et al. (27) found that partitioning to shoots and grains with increasing $\mathrm{Cd}$ supply was markedly higher in Svevo cultivar. They also reported that high $\mathrm{Cd}$ content in grains of Svevo cultivar may be related to the high allocation of biomass in roots during vegetative growth stage coupled with high post-heading dry matter accumulation and root to grain re-mobilization. Higher accumulation of elements from the soil in the plant is a desired trait to obtain higher yield and quality; therefore, breeding studies have focused on improving yield components to increase crop yield (28). Due to these concerns, modern wheat varieties tend to accumulate elements such as $\mathrm{Cd}$ in the grain $(21,22,28)$. However, since high $\mathrm{Cd}$ content in the grain is not a desirable trait, cultivars with alleles associated with low $\mathrm{Cd}$ content and high yield should be given first priority in durum wheat breeding.

Table 4. The results of principal component analysis (PCA) of plant organ (underground parts, stems and grains) contribution to $\mathrm{Cd} \mathrm{ac}$ cumulation in durum wheat cultivars

\begin{tabular}{llc} 
Plant organ & PC1 & PC2 \\
Underground parts (root and stubble) & 43.51 & 3.19 \\
Stem & 38.82 & 17.10 \\
Grain & 17.68 & 79.72 \\
\hline
\end{tabular}

\section{CONCLUSIONS}

In a nutshell, $\mathrm{Cd}$ is released into the environment in many ways, including the use of intensive phosphate fertilizers, sewage sludge and fossil fuel combustion in addition to natural Cd sources, and therefore Cd contamination of the soils has increased worldwide. In recent years, lower accumulation of $\mathrm{Cd}$ has been a breeding priority in addition to other quality traits especially in Cd-contaminated soils, and many wheat varieties have been developed with marker-assisted breeding. In this study, molecular analysis showed that $24 \mathrm{du}-$ rum wheat cultivars, one emmer wheat and four wild emmer genotypes accumulated high mass fractions of $C d$, while 68 genotypes had the allele associated with low $\mathrm{Cd}$ accumulation. Moreover, these molecular findings were supported by elemental analyses performed after pot experiment using a small set of 14 cultivars. In conclusion, since chemical or elemental analyses are expensive and time consuming for selection of genotypes with low levels of $\mathrm{Cd}$, marker-assisted studies can be effectively used for both selection and introgression of Cdu1 alleles to adapted common durum wheat cultivars with low grain $\mathrm{Cd}$ content.

\section{FUNDING}

This study was financially supported by The Scientific Research Projects Unit of Akdeniz University (grant no. FBA2017-2402).

\section{CONFLICT OF INTEREST}

The authors declare that they have no any conflicts of interest.

\section{SUPPLEMENTARY MATERIAL}

All supplementary material is available at www.ftb.com.hr.

\section{ORCID ID}

M. Tekin (1) https://orcid.org/0000-0002-3447-1586

A. Cat (1) https://orcid.org/0000-0002-5638-0319

S. Sönmez ㄴ) https://orcid.org/0000-0003-2753-2296

T. Akar (ㄴ https://orcid.org/0000-0002-3488-3943

\section{REFERENCES}

1. Tongarlak S. Determination of responses of different wheat and barley varieties to cadmium [PhD Thesis]. Konya, Turkey: Selçuk University; 2010 (In Turkish).

2. Rizwan M, Ali S, Abbas T, Zia-ur-Rehman M, Hannan F, Keller C,et al. Cadmium minimization in wheat: A critical review. Ecotoxicol Environ Saf. 2016;130:43-53. https://doi.org/10.1016/j.ecoenv.2016.04.001

3. Erdem H, Tosun YK, Ozturk M. Effect of cadmium-zinc interactions on growth and $\mathrm{Cd}-\mathrm{Zn}$ concentration in durum and bread wheats. Fresen Environ Bull. 2012;21(5):1046-51.

4. Gallego SM, Pena LB, Barcia RA, Azpilicueta CE, lannone MF, Rosales EP, et al. Unravelling cadmium toxicity and tolerance in plants: Insight into regulatory mechanisms. Environ Exp Bot. 2012;83:33-46.

https://doi.org/10.1016/j.envexpbot.2012.04.006

5. Smidt GA, Landes FC, Machado de Carvalho L, Koschinsky A, Schnug E. Cadmium and uranium in German and Brazilian phosphorous fertilizers. In: Merkel B, Schipek M, editors. The new uranium mining boom: Challenge and lessons learned. Berlin, Germany: Springer; 2011. pp. 167-75. https://doi.org/10.1007/978-3-642-22122-4_20

6. Jansson G. Cadmium in arable crops: The influence of soil factors and liming [PhDThesis]. Uppsala, Sweden: Swedish University of Agricultural Sciences; 2002.

7. Ysart G, Miller P, Croasdale M, Crews H, Robb P, Baxter M, et al. 1997. UK total diet study dietary exposures to aluminium, arsenic, cadmium, chromium, copper, lead, mercury, nickel, selenium, tin and zinc. Food Addit Contam. 2000;17(9):775-86.

https://doi.org/10.1080/026520300415327

8. Braun HJ, Atlin G, Payne T. Multi-location testing as a tool to identify plant response to global climate change. In: Reynolds MP, editor. Climate change and crop production. Oxfordshire, UK: CABl; 2010. pp. 115-38. https://doi.org/10.1079/9781845936334.0115

9. Gao J, Sun L, Yang X, Liu JX. Transcriptomic analysis of cadmium stress response in the heavy metal hyperaccumulator Sedum alfredii Hance. PloS ONE. 2013;8(6):e64643. https://doi.org/10.1371/journal.pone.0064643

10. Codex Alimentarius Comission. General standard for contaminants and toxins in food and feed (Codex standard 193-1995). Rome, Italy: Food and Agriculture Organization 
of the United Nations and World Health Organization (FAO/ WHO); 2015. Available from: http://www.fao.org/input/ download/standards/17/CXS_193e_2015.pdf.

11. Clarke JM, Clarke FR, Pozniak CJ. Forty-six years of genetic improvement in Canadian durum wheat cultivars. Can J Plant Sci. 2010;90(6):791-801.

https://doi.org/10.4141/cjps10091

12. Pozniak CJ, Clarke JM. CDC alloy durum wheat. Can J Plant Sci. 2017;97(2):385-9.

https://doi.org/10.1139/cjps-2016-0128

13. Pozniak CJ, Clarke JM. CDC dynamic durum wheat. Can J Plant Sci. 2017;97(2):380-84. https://doi.org/10.1139/cjps-2016-0160

14. Clarke JM, Leisle D, Kopytko GL. Inheritance of cadmium concentration in five durum wheat crosses. Crop Sci. 1997;37(6):1722-6.

https://doi.org/10.2135/cropsci1997.0011183X003700060008x

15. Knox RE, Pozniak CJ, Clarke FR, Clarke JM, Houshmand S, Singh AK. Chromosomal location of the cadmium uptake gene (Cdu1) indurum wheat. Genome. 2009;52(9):741-7. https://doi.org/10.1139/G09-042

16. Wiebe K, Harris NS, Faris JD, Clarke JM, Knox RE, Taylor GJ, Pozniak CJ. Targeted mapping of Cdu1, a major locus regulating grain cadmium concentration in durum wheat (Triticum turgidum L. var durum). Theor Appl Genet. 2010;121(6):1047-58. https://doi.org/10.1007/s00122-010-1370-1

17. Zimmerl S, Lafferty J, Buerstmayr H. Assessing diversity in Triticum durum cultivars and breeding lines for high versus low cadmium content in seeds using the CAPS marker usw47. Plant Breed. 2014;133(6):712-7.

https://doi.org/10.1111/pbr.12218

18. Doyle JJ, Doyle JL. A rapid total DNA preparation procedure for fresh plant tissue. Focus. 1990;12:13-15.

19. SAS Statistical Software, v. 9.0, SAS Institute Inc., Cary, NC, USA; 2002. Available from: https://www.sas.com/en_us/ software/stat.html.

20. XLSTAT Statistical Software for Excel, v. 2016.1, Addinsoft Co., Paris, France; 2016. Available from: https://www.xlstat. com/en/.
21. Vergine M, Aprile A, Sabella E, Genga A, Siciliano M, Rampino $P$, et al. Cadmium concentration in grains of durum wheat (Triticum turgidum L. subsp. durum). J Agr Food Chem. 2017;65(30):6240-6.

https://doi.org/10.1021/acs.jafc.7b01946

22. Perrier F, Yan B, Candaudap F, Pokrovsky OS, Gourdain E, Meleard $B$,et al. Variability in grain cadmium concentration among durum wheat cultivars: Impact of aboveground biomass partitioning. Plant Soil. 2016;404(1-2):307-20.

https://doi.org/10.1007/s11104-016-2847-8

23. Liu JG, Liang JS, Li KQ, Zhang ZJ, Yu BY, Lu XL, et al. Correlations between cadmium and mineral nutrients in absorption and accumulation in various genotypes of rice under cadmium stress. Chemosphere. 2003;52(9):1467-73.

https://doi.org/10.1016/S0045-6535(03)00484-3

24. Jalil A, Selles F, Clarke JM. Effect of cadmium on growth and the uptake of cadmium and other elements by durum wheat. J Plant Nutr. 1994;17(11):1839-58.

https://doi.org/10.1080/01904169409364851

25. Harris NS, Taylor GJ. Cadmium uptake and translocation in seedlings of near isogenic lines of durum wheat that differ in grain cadmium accumulation. BMC Plant Biol. 2004;4:4. https://doi.org/10.1186/1471-2229-4-4

26. Harris NS, Taylor GJ. Cadmium uptake and partitioning in durum wheat during grain filling. BMC Plant Biol. 2013;13:103.

https://doi.org/10.1186/1471-2229-13-103

27. Arduini I, Masoni A, Mariotti M, Pampana S, Ercoli L. Cadmium uptake and translocation in durum wheat varieties differing in grain-Cd accumulation. Plant Soil Environ. 2014;60(1):43-9.

https://doi.org/10.17221/416/2013-PSE

28. Arduini I, Masoni A, Ercoli L, Mariotti M. Grain yield, and dry matter and nitrogen accumulation and remobilization in durum wheat as affected by variety and seeding rate. Eur J Agron. 2006;25(4):309-18.

https://doi.org/10.1016/j.eja.2006.06.009 